\title{
Accessions to the WTO: Case Study over Nuclear Proliferation
}

\author{
Ece Aksop ${ }^{1}$ \\ ${ }^{1}$ METU, PhD Candidate
}

\begin{abstract}
Current political developments indicate that the quest for nuclear weapons is not one-way, it is possible to achieve (at least the talk of) nonproliferation. At this stage, what follows next seems to be a legitimate question to be analyzed.

As globalization makes political borders more porous, it also makes political issues more connected. Despite that, and despite also the academics are pushing for more interdisciplinarity in research and in analysis, there is still a tendency to solve security problems with hard measures. As soft power is a useful tool, soft measures can also be beneficial in introducing solutions for hard issues like nuclear proliferation.

Argument here emanates from the fact that WTO accession negotiations is not a purely technical issue. Therefore, accession can be used for political purposes like providing "carrots" with regards to Iran's nuclear program. Given the positive course of the negotiations and emanating hopes of preventing proliferation, engagement may not only be timely but also an appropriate tool in preventing history repeat itself, newly reached deal be broken, and Iran follow the footsteps of North Korea.

Thinking in this line, it is possible to use WTO accession procedure to extract further concessions from acceding countries. In a hypothetical Iranian accession, it is possible to take Iran agreeing to be subject to future UN-imposed sanctions implemented by the WTO without carrying them to a panel, and to agree with unilateral inspections by a determined international organization or by the exporting country itself as a WTO-plus concession. A WTO-minus concession can be Iran agreeing not to look for absolute free trade to curb export controls, and respect the Security Exceptions provided under GATT for each individual member country. As such, a hard question like proliferation will be (assisted to be) settled in a soft environment, proving that issue linkages is possible if we are ready to operate in a multidimensional world.
\end{abstract}

Keywords: Nuclear proliferation, interdisciplinarity, security, trade.

\section{Introduction}

Recent developments indicate that the quest for nuclear weapons is not one-way, it is not obligatory to proliferate and is possible to achieve (at least the talk of) nonproliferation. It thus necessitates the question of what follows next. How to normalize relations with an ex-proliferator, how to achieve engagement and even, how to maintain a level of checks-and-balances that helps not only building trust but also countering nonproliferation are all waiting for further analysis.

This article will argue that while what is known as the Iranian nuclear deal is advancing, proliferation as an international question can change the basket and shift itself from the security to the non-security sphere. As such, it is argued, de-securitization as well as normalization can be achieved. The shift of baskets envisioned here will take place between security and commerce; the United Nations (UN) representing the former and the World Trade Organization (WTO) the latter.

The choice of institutions is by no means coincidental. The UN, without doubt, amounts to the security elite of the international sphere, while securitization being handled by the Security Council. The WTO, on the other hand is simply a ratchet-up institution - further liberalization could not be achieved as Doha Round negotiations has stagnated. All the WTO could promise is, basically, a front to hold against protectionism, tariff wars, and discrimination. This article will, therefore, open up new avenues for the WTO by taking its most influential part, the Dispute Settlement, and improving it into a forum where export controls can be discussed from a commercial as well as legal point of view.

\subsection{Membership to the WTO}

There are two types of members of the WTO. The first ones are the "original members," the signatories of the GATT as well as those that became members before March 1997. [1] The countries that are not the "original 
members" of the WTO can become parties to the Organization through a long process of negotiations. Known as the accession negotiations, the process covers bilateral and multilateral negotiations in which the candidate country makes its trade-related legislation as well as policies transparent, and engages in a series of bargaining on tariff levels.

Marrakesh Agreement Ar XII regulates the accession process. The Article reads as:

1. Any State or separate customs territory possessing full autonomy in the conduct of its external commercial relations and of the other matters provided for in this Agreement and the Multilateral Trade Agreements may accede to this Agreement, on terms to be agreed between it and the WTO. Such accession shall apply to this Agreement and the Multilateral Trade Agreements annexed thereto.

2. Decisions on accession shall be taken by the Ministerial Conference. The Ministerial Conference shall approve the agreement on the terms of accession by a two-thirds majority of the Members of the WTO.

3. Accession to a Plurilateral Trade Agreement shall be governed by the provisions of that Agreement.

"The Ar XII is remarkably brief and gives no guidance on the 'terms to be agreed' which is left to the negotiations between the members and the acceding country."[2] The lack of clear procedural guidance results in pullings and haulings during the negotiation period, and as the WTO is a consensus-based organization, bilateral negotiations determine the fate of the whole accession process. Any mutual problem can slow down if not block the whole process easily.

\subsubsection{Asymmetric Nature of Negotiations}

In addition to the consensus principle that gives each and every single member the power to block the whole process, there are two other issues that create asymmetry between the members and the acceding countries.

First is the most-favored-nation (MFN) rule: the acceding country negotiates the concessions on a bilateral basis, but has to grant them on an MFN basis. Namely, in order to become a member, the acceding country has to solve all its problems on bilateral basis, and pay the price of the solution not only to its negotiating partner but also to all the members. Critics take this reality one step further, and argue that the consensus principle creates a system that is structurally biased against the acceding country, because "any unresolved issue between an applicant and a single member can result in a deadlock ... As a consequence, a remarkable outcome that emerges out of this process is that bilateral agreements during accession negotiations may take over multilateral trading rules and procedures." [3]

Besides the MFN rule resulting with the overall triumph of bilateralism over multilateralism, critics also pointed out to the voice concerns that accession process is increasingly colored by WTO-plus demands. Highlighting the fact that the WTO members offer nothing but membership in return, critics claim that the whole process is flawed and "acceding countries may feel a lack of ownership of the reforms they have committed to undertake."[4] In line with this, they maintain that while formal rules of accession remained the same since 1947, the actual practice has changed in time. "What was for many developing countries and transition economies little more than the formal transmittal of bound tariff rates in the pre-1995 era has now become a procedure whereby WTO members in general, and the Quad in particular [the US, the EU, Japan and Canada], use their unique negotiation position by virtue of inherent flaws of the accession process, to win ever greater concessions from acceding countries, irrespective of their size and economic significance, in the course of their accession to the WTO." [5]

\subsubsection{WTO-Plus and -Minus Commitments}

The WTO is a "take it or leave it" type of a monolithic package. It is called as the "single undertaking," neither members nor acceding countries have the option of "GATT a la carte" since the conclusion of the Uruguay Round. [6] In this sense, acceding countries know their rights and obligations beforehand. However, critics argue that the vagueness of the whole process "have resulted in the proliferation of 'WTO-plus' and 'WTO-minus' demands by members pressing applicant countries for commitments beyond the requirements of the WTO agreements."[7]

A general example for a WTO-plus commitment is the push for privatization of state trading enterprises. Under the GATT 1994, there is no such requirement, yet major developed countries press for privatization as well as for a commitment to report periodically to the Working Party. 
If privatization is a WTO-plus demand, an example for a WTO-minus demand can be deprivation of acceding countries from the special and differential treatment.[8] For instance, "acceding countries have not been allowed to use the 'tarriffication method' for the existing quantitative restrictions in agriculture or to use special safeguard provisions for the same sector." [9] Another example is CIS countries, some of which applied for the developing country status on the way to acceding to the WTO. Aim was to relieve the obligations regarding the liberalization of the agriculture sector. None was granted; yet only Kyrgyzstan was allowed to use input and investment subsidies, i.e. despite not being recognized as a developing country it was allowed to use measures available only for developing countries.[10] We will elaborate on how the WTO-plus and -minus commitments can be used in Iran's accession protocol further below.

\section{Iran's Accession Adventure}

Regardless the flaws in the procedure, there are currently 22 states that want to benefit from the fruits of the WTO system. The Speedy Gonzales ever in the negotiation process is Kyrgyzstan with two years, whereas the Algerian accession negotiations still continue since 1987. Looking from this perspective, Iranian adventure seems to have taken an average amount of time - up to now, at least.

Iran applied to the WTO in 1996. Its Working Party was established roughly a decade later, in 2005. Since then, as there is no chairperson appointed, the Working Group could not have gathered for an official meeting. Despite that, Iran submitted its memorandum in 2009, and an exchange of questions took place in 2011, [11] but this does not remove the fact that Iranian accession negotiations are under the heavy influence of politics.

\subsection{Sui Generis Nature of Iranian Accession: Role of Politics}

Before moving on to the accession negotiations, let's pause a little here and make a short historical trip on Iranian nuclear quest.

Iran first encountered the nuclear technology during the Cold War. The US begun planting the seeds of the nuclear program back in 1957 as "[t]he shah emerged as an important American ally in the Persian Gulf." [12] In the following year, Iran became a party to the International Atomic Energy Agency (IAEA). In the following decade, it also became party to the Nuclear Nonproliferation Treaty (NPT) and declared its desire to have nuclear reactors. In 1970s, the US supported Iran in developing non-oil energy bases, [13] even to a degree that just in the year before the Revolution, US-Iran Nuclear Energy Agreement was signed. "Had the bilateral agreement put into effect it would have resulted in wide-ranging nuclear assistance from the US to Iran." [14]

At that time Iran managed to complete six nuclear reactors, of course with intensive assistance not only from the US but also the Europeans, namely, Germany, France and Belgium. Soon before the Revolution, the nuclear program began to lose its pace. The Shah government suspended negotiations with the West Germany and the US, and limited its reactor purchases from Kraftswerk Union (Siemens) for Bushehr, and one other from Fromatome for Darkhvin.[15] The cooperative spirit abandoned the nuclear discourse after the Islamic Revolution in 1979.

Following the Revolution, the new leadership revised all the policies of the Shah era, including the nuclear ones. The deals for two units of reactors were cancelled; additionally Iran announced that it "would not purchase enriched uranium from ... Eurodif... of which the Shah had acquired a ten per cent share in 1974 by lending \$1 billion to the French-led consortium." [16] All these steps turned into conflicts as Iran demanded full refunding and France declared in the early 1980s that it would not repay Iran. Similarly, when Iran tried to get its money back from Germany and demanded 2.1 billion DM; the firm in turn sought for 1.8 billion DM bill of the machinery produced but never delivered because of the suspension of the agreements. [17] The firm neither paid the money back, nor finished construction, or delivered the already-purchased machineries.[18]

In addition to the efforts to erase Shah's legacy, Iran-Iraq War (1980-1988) also played an important role in defining Iranian policies towards armament. That is to say, it was not only a pure criticism of Shah's efforts to strengthen and modernize Iranian armed forces [19] for amounting to a huge waste of national wealth, [20] but also the inability to win over Iraq during a period of eight years that shaped Iranian policies in the postRevolutionary years. Especially the use of chemical weapons by Iraqis made Iranians seek for an effective international arms control policies. The new state ideology also assisted this policy as Islam would not approve mass destruction. 
Despite some like Bobi Pirseyedi argue that arms control was a tool for remedying military weakness, [21] some others like Michael Eisenstadt argue just the opposite by stating that the inability to win over Iraq traumatized Iran and in 1989, it started a modernization project with regard to its armed forces. However, not only the small size of Iran's land forces or its inability in replacing combat losses, but also its relative naval inferiority with regards to the US and the arms embargoes made it impossible for Iran to afford a conventional war. In addition to these factors, there was also the given target of undermining US dominance in the Gulf. [22] Thus, argument went on, for Iran, acquiring non-conventional weapons climbed up to the top of the agenda.

Officially, Iran has neither tacitly nor overtly declared to pursue a nuclear weapon program. The official rhetoric always focused on the need of electricity. Looking through Iranian prism, increasing population meant increasing electricity demands. Simply because "a barrel of oil is too precious... to be used for generating electricity," [23] the search for nuclear energy was justified. However, following the disclosure of Iranian quest in 2002, the Western response to the Iranian claims for peaceful nuclear energy was based on the fact that Iran is the largest natural gas reserve owner, [24] hence the quest was alleged to be not for electricity but for weapons.

Besides being an international issue, the Iranian quest for nuclears had multiple other dimensions: Domestically, the very fact that the program has been on the agenda for nearly half a century shows the administrative dedication. Politically, the US engagement in the region makes Iran feel encircled by the US which enjoys a presence in Afghanistan and Iraq, and holds military bases in Turkey, Saudi Arabia and Oman. Having six of the existing -at least- eight nuclear powers closeby, [25] the Iranian sense of insecurity is understandable. [26] Strategically, the increasing gap between the haves and have-nots adds fuel to the imbalance and insecurity in the region; and " $[\mathrm{p}]$ art of the problem in ... nuclear disarmament is that international community has, as yet, developed no alternative to a reliance on nuclear deterrence". [27] But logically, in a region where nuclear doctrines related with "non-resort" and "not military but diplomatic weapon" notions are absent, proliferation may actually be another headache.

The only solution found so far to prevent Iran becoming a nuclear-weapon country has been implementing a sanctions regime. In addition to the universal UN sanctions, there have also been unilateral US and EU sanctions against Iran - claim being ensuring the peace and security by denying Iran from nuclear weapons capability. These sanctions, though being a part of extensive and long endured negotiations, cover a wide range, including but not limited to investment and travel bans and export controls. For sake of brevity, we shall here focus only trade in goods, hence discuss only the impact of export controls on accession negotiations and post-membership period.

\subsection{Allure d'Escargot: History of Iranian Accession Negotiations}

As stated above, negotiations is a long and hard way heading to membership. For Iran, only the formation of the Working Party took nine years and 81 meetings of the General Council. Considering that accession itself takes a total of 20 meetings in average, and usually the request for establishment of the Working Party does not take more than a few months, it is safe to state that Iran made a slow-paced start.

Iran applied to the WTO in 1996, and a working party was established in 2005. Working Group has not convened yet; however, Iran submitted its accession memorandum on 29 November 2009, and an exchange of questions and replies took place only on 8 December 2011.[28]

As mentioned above, the accession process is actually member-driven. Because of the consensus rule, each and every single member can block the negotiations, ask for more concessions, and in the end, decline the request for membership. This gives an absolute disadvantage to the acceding countries because the negotiations does not start on equal footing.

In addition to this inherent imbalance, the sui generis nature of the Iranian accession complicates things even further.[29] Iranian accession negotiations are heavily influenced by political environment; hence economic give-and-take type of solution does not seem to be enough for neither party which is concerned with Iran's accession to the WTO - this goes especially for the US.

\subsubsection{Asymmetry in Accession Negotiations: Political Issues}

The US-Iran relationship has a long history. Even during the periods of close political relations, trade volume was low because Iran's main trading partners were Germany, Russia and the UK. Only for a brief period 
during the World War 2 did the US become Iran's main trading partner by exporting food, arms and other wartime related items. The US attempt to introduce the MFN principle to the bilateral trade relations were refused by Iran, which already had given generous concessions with the Turkmencai Treaty to Russia following its humiliating defeat against the latter. Hence, Iran has long been carrying this psychological baggage and feeding prejudices towards MFN-like concessions for it perceived them as a variation of capitulations. [30]

While the $20^{\text {th }}$ century was marked with the discovery of oil in the region, [31] the 1970s were marked with the oil price crisis. As a result, the UNCTAD-driven Generalized System of Preferences (GSP) scheme, which offers preferential market access opportunities to developing countries, was put in the pipeline with an exclusion of oil exporting countries. "The US GSP scheme provided preferences to over four thousand products from over one hundred developing countries. It excluded all OPEC members from the preferences because of the 1973 oil embargo. Iran, which had not participated in the embargo, was also denied preferential access to US markets, indicative also of the highly politicized Iran-US trade and economic ties." [32]

The impact of the 1979 Revolution and the Hostage Crisis is also seen overtly when one compares the progress in the accession processes of some other countries. As observed, " "[i]n contrast with Iran and Syria, the General Council approved requests from Afghanistan and Iraq to begin negotiations to join the WTO' [despite the fact that the widespread presence of v]iolence in these two countries undermines the rule of law needed for the membership to mean anything in practice." [33] There, indeed, is not much to be said following this observation.

\subsubsection{Asymmetry in Accession Negotiations: Concessions}

North Korea has been under sanctions for decades, yet gained the nuclear capability. Consequently, we can conclude that an isolated Iran can well keep searching for a nuclear capability. The tighter the implementation or the perception of the sanctions is, the higher the chances of backfire in the sense that Iran will search for a domestic capability. Given the fact that with the Joint Comprehensive Plan of Action (Iran deal - 14 July 2015) the negotiations have yet entered into a new phase and there is a general hope in preventing proliferation, engagement may not only be timely but also appropriate.

It should be kept in mind that while main aim is to prevent Iran become a North Korea, as the deal is about to achieve a great step forward in nonproliferation, it is always possible to break the deal and undo the nonproliferation achieved. Moreover, the negotiations as well as the deal reached may (or may not) be a tactical retreat. In the end, history shows many examples when Iranians sat and remained on the table solely for purposes of buying time. It was Rowhani himself who said "that the concessions which Iran appeared to make when it agreed to suspend particular activities actually cost the country nothing ... because the activities ... suspended were those that Iran's nuclear technologists were not ready to pursue ... [and] during that period [of suspension] we could concentrate all of our efforts and energy on other activities ... The day when Natanz was suspended, we put all our effort into Esfahan. Now that Esfahan is in suspension, we are fixing other existing flaws." [34]

Argument for engagement here derives from the belief that any country that is marginalized and left outside of the system will have motivations to securitize, and will be difficult to desecuritize (example being North Korea). [35] The WTO, as being the only international organization to set and regulate global trade, can be used as a tool for nonproliferation in terms of engaging Iran. In doing so, the members will not be conceding much, because the WTO system allows them shape the process: As negotiations are actually member-driven and tailormade for each acceding country, accession protocol of Iran can contain WTO-plus or -minus commitments. Therefore, the WTO can be used as a tool to engage with Iran and prevent further isolation of the country, hence, can well assist the nonproliferation process.

In our case, for the accession of Iran, a WTO-plus concession can result in Iran accepting (i) to be subject to future UN-imposed sanctions implemented by the WTO without carrying them to a panel under the Dispute Settlement Unit, and (ii) to agree with unilateral inspections by a determined international organization or by the exporting country itself. A WTO-minus concession can be Iran agreeing not to sue for export control regimes of member countries [36] and in return getting a full list of controlled items without any "catch-all" phrase -- hence it can get predictability: a fixed or periodically reviewed list provides more transparency than discretion-based "catch-all" systems. 


\section{Conclusion}

This article emanates from the idea that as globalization makes political borders more and more porous, it also makes political issues more and more connected. While the academics are pushing for more interdisciplinarity in research and in analysis, there is still a tendency to solve security problems with hard measures. As soft power is a useful tool, we argue, soft measures can also be beneficial in introducing solutions for hard issues like nuclear proliferation.

The case this paper focused on was Iran and its hypothetical entry to the WTO. The claim was that Iraq as well as Afghanistan proceeded further in accession negotiations than did Iran, indicating that accession is not a purely technical issue. Therefore, it can be used for political purposes like providing "carrots" in the ongoing negotiations on Iran's nuclear program. Given the positive course of the negotiations and emanating hopes of preventing proliferation, engagement may not only be timely but also an appropriate tool in preventing history repeat itself, and Iran follow the footsteps of North Korea.

The research here indicates that it is possible to benefit from WTO accession procedure to extract further concessions from acceding countries. In a hypothetical Iranian accession, we argued, it is possible to take Iran agreeing to be subject to future UN-imposed sanctions implemented by the WTO without carrying them to a panel, and to agree with unilateral inspections by a determined international organization or by the exporting country itself as a WTO-plus concession. A WTO-minus concession can be Iran agreeing not to look for absolute free trade to curb export controls, and respect the Security Exceptions provided under GATT for each individual member country. As such, we argue, a hard question like proliferation will be (assisted to be) settled in a soft environment, proving that issue linkages is possible if we are ready to operate in a multidimensional world.

\section{References}

[1] The initial deadline was 1 January 1997; yet the General Council extended the deadline shortly. See P. van den Boosche, The Law and Policy of the World Trade Organization: Text, Cases and Materials, UK: Cambridge University Press, 2009, $2^{\text {nd }}$ ed., p. 108.

[2] UNESCAP, Accession to the World Trade Organization: Issues and Recommendations for Central Asian and Caucasian Economies in Transition, New York: United Nations, 2001, p. 7.

[3] R. Grynberg, M. Dugal, and M. A. Razzaque, An Evaluation of the Terms of Accession to the World Trade Organization: A Comparative Assessment of Services and Goods Sector Commitments by WTO Members and Acceding Countries, London: Commonwealth Secretariat, 2006, p. 4.

http://dx.doi.org/10.14217/9781848598744-en

[4] Ibid, p. x.

[5] Ibid, p. 4.

[6] Exception is plurilateral agreements.

[7] Grynberg, Dugal, and Razzaque, An Evaluation of the Terms of Accession to the World Trade Organization, p. 4.

[8] See WTO webpage for further. Available: http://www.wto.org/english/tratop_e/devel_e/dev_special_differential_provisions_e.htm.

[9] Grynberg, Dugal, and Razzaque, An Evaluation of the Terms of Accession to the World Trade Organization, p. 5. Footnotes omitted.

[10] M. Roberts and P. Wehrheim, "Regional Trade Agreements and WTO Accession of the CIS Countries," International Trends Intereconomics, Nov/Dec 2001, p. 319.

[11] See WTO official webpage on accessions. Available: www.wto.org/english/thewto_e/acc_e/aq_iran_e.htm.

[12] Ibid, p. 8.

[13] Notice should be made, however, that the main if not the only aim of encouraging Iran enjoy nuclear technology was to get the large sums of oil-money back. Mohammed Sahimi, Iran's Nuclear Program, 2003-2005, “Part I: Iran's Nuclear Program: Its History", p. 3. All six parts available: www.payvand.com.

[14] B. Pirseyedi, Arms Control and Iranian Foreign Policy: Diplomacy of Discontent, UK: Routledge, 2012, p. 116.

[15] Ibid.

[16] Ibid.

[17] NTI, "Nuclear Chronology: 1957-1985" in Iranian Country Profile: Nuclear, pp. 3, 8, 14, 18-9. Available: www.nti.org/e_research/profiles/Iran/ 182 5_1 826.html.

[18] Sahimi, "Part VI: The European Union's Proposal, Iran's Defiance, and the Emerging Crisis", pp. 14-5.

[19] Pirseyedi, Arms Control and Iranian Foreign Policy, p. 32. 
[20] Ibid, p. 34.

[21] Ibid, esp. chap. 2.

[22] M. Eisenstadt, Iranian Military Power: Capabilities and Intentions, Washington DC: The Washington Institute for Near East Policy, 1996, p. 3, 35.

[23] Shah quoted in Sahimi, Iran's Nuclear Program, "Part II: Are Nuclear Reactors Necessary?”, p. 3.

[24] British Petroleum, BP Statistical Review of World Energy, June 2015. Available: http://www.bp.com/en/global/corporate/about-bp/energy-economics/statistical-review-of-world-energy.html.

[25] These countries are China, India, Israel, Russia and Pakistan bordering Iran, and the USA; being in Iraq and Afghanistan. The other two states of the nuclear club are France and the UK.

[26] Immanuel Wallerstein, “After Iraq, Iran?” Binghamton Commentary, No. 146, 1 October 2004.

[27] M. el-Baradei, "Nuclear-Weapon-Free Zones: Pursuing Security, Region by Region", statement given on 26 April 2005. Available: https://www.iaea.org/newscenter/statements/nuclear-weapon-free-zones-pursuing-security-regionregion.

[28] See official webpage of accessions of WTO: www.wto.org/english/thewto_e/acc_e/aq_iran_e.htm.

[29] Unless stated otherwise, below part is mainly from S. Jalal Alavi, "Accession of Iran to the World Trade Organization: A Legal-Political Overview," Iranian Review of Foreign Affairs, 1:3 (2010).

[30] Subsequent treaties with the US, like the 1955 Treaty of Amity, excluded trade and investment related provisions too.

[31] See D. Yergin, Prize: The Epic Quest for Oil, Money and Power, US: Simon\&Schuster, 1991; M. Klare, Blood and Oil: The Dangers and Consequences of America's Growing Dependency on Imported Petroleum, New York: Metropolitan Books, 2004.

[32] S. J. Alavi, "Accession of Iran to the World Trade Organization: A Legal-Political Overview," Iranian Review of Foreign Affairs, vol. 1:3, 2010, p. 146.

[33] Quoted in ibid, p. 149; footnote omitted.

[34] G. Perkovich, "Iran's Nuclear Program after the 2005 Elections," in the Emirates Center for Strategic Studies and Research, Iran's Nuclear Program: Realities and Repercussions, Abu Dhabi: ECSSR, 2006, pp. 44-5. Emphasis original.

[35] B. Buzan, O. Wæver and J. de Wilde, Security: A New Framework for Analysis, London: Lynne Rienner Publishers, 1998.

[36] For a certain transitionary period of time, as full waiver will completely run against the letter and spirit of the GATT. 